\title{
A novel pathway for vitamin A signaling mediated by RXR heterodimerization with NGFI-B and NURR1
}

\author{
Thomas Perlmann ${ }^{1}$ and Lottie Jansson \\ Laboratory of Developmental Biology, Department of Cell and Molecular Biology, Medical Nobel Institute, Karolinska \\ Institute, S-171 77 Stockholm, Sweden
}

\begin{abstract}
In addition to its role as a 9-cis retinoic acid receptor, RXR has an important role in the regulation of multiple hormonal pathways through heterodimerization with nuclear receptors. Here, we show that two orphan receptors, NGFI-B and NURR1, which have been shown previously to interact with DNA as monomers, also can heterodimerize with RXR. These heterodimers bind selectively to a class of retinoic acid response elements composed of direct repeats spaced by 5 nucleotides. In this respect they are similar to heterodimers formed between RXR and the receptor for all-trans retinoic acid, RAR. However, whereas RXR is inhibited in the RXR-RAR heterodimer, NGFI-B/NURR1 promote efficient activation in response to RXR ligands and therefore shift RXR from a silent to an active heterodimerization partner. These data show that NGFI-B and NURR1 can increase the potential of RXR to modulate gene expression in a ligand-dependent manner by allowing a distinct class of direct repeats to serve as specific RXR response elements. Because expression of both NGFI-B and NURR1 is rapidly induced by various growth factors, these findings also suggest a novel mechanism for convergence between vitamin A or retinoid and growth factor signaling pathways.
\end{abstract}

[Key Words: 9-Cis retinoic acid; immediate-early gene; nuclear hormone receptor; orphan receptor; retinoic acid; vitamin A]

Received July 21, 1994; revised version accepted February 13, 1995.

Growth factors induce several immediate-early genes that often are involved in the control of cell growth and differentiation (Herschman 1991). One of these, NGFI-B (also called Nur77; Hazel et al. 1988; Milbrandt 1988), is a member of the nuclear hormone receptor family of ligand-inducible transcription factors (Evans 1988; Green and Chambon 1988). However, a ligand has not yet been identified for NGFI-B, and therefore it belongs to the category of "orphan receptors." Although our knowledge of NGFI-B function is limited, it is clear that its responsiveness to growth factors is important. First, NGFI-B has been implicated in the control of steroidogenesis, because it is able to activate the adrenal-specific steroid 21-hydroxylase gene in response to corticotropin (ACTH; Wilson et al. 1993a). Second, NGFI-B appears to be required for elimination of self-reactive thymocytes during T-cell development through apoptosis, a process triggered by the activation of cell surface $\mathrm{T}$-cell antigen receptors (Liu et al. 1994; Woronicz et al. 1994). These findings suggest that NGFI-B has an important function in mediating responses to various cell stimulatory signals. A critical step in furthering our knowledge of this function is to understand the regulatory targets of NGFIB. Hence, as NGFI-B is a transcription factor that mod-

\footnotetext{
${ }^{1}$ Corresponding author.
}

ulates gene expression by binding to specific DNA sequences [hormone response elements (HREs)], it will be necessary to clearly define such binding sites.

NGFI-B has been shown to belong to a new group of orphan nuclear receptors that bind to specific DNA elements as monomers (Wilson et al. 1991, 1993b). In contrast, several other nuclear receptors such as the all-trans retinoic acid (RA) receptor (RAR), the thyroid hormone receptor (TR), the vitamin $\mathrm{D}$ receptor, and the peroxisome proliferator-activated receptor bind to cognate HREs as heterodimers with the receptor for 9-cis RA (RXR; Yu et al. 1991; Bugge et al. 1992; Kliewer et al. 1992a,b; Leid et al. 1992; Marks et al. 1992; Zhang et al. 1992a). In many cases, HREs are composed of direct repeats of a common half-site sequence (AGGTCA) with the spacing between such repeats playing an important role for specificity (Näär et al. 1991; Umesono et al. 1991; Vivanco-Ruiz et al. 1991). Thus, in addition to its role as a 9-cis RA-activated receptor (Heyman et al. 1992; Levin et al. 1992; Mangelsdorf et al. 1992; Zhang et al. 1992b; Allenby et al. 1993), RXR plays a central role in controlling multiple hormonal pathways through heterodimerization.

A critical dimerization interface in heterodimerizing receptors is localized to the carboxy-terminal ligandbinding domain (Forman et al. 1989; Glass et al. 1989; 
Yu et al. 1991; Kliewer et al. 1992a; Leid et al. 1992; Marks et al. 1992; Au-Fliegner et al. 1993; Zhang et al. 1994). Because NGFI-B binds to DNA as a monomer, no function has yet been ascribed to the NGFI-B carboxyterminal domain. Significant similarity between the heterodimerizing receptors and NGFI-B can be observed within this region, which led us to investigate the possibility that this receptor also would be able to form dimers. Our experiments demonstrate that NGFI-B and the closely related orphan receptor NURR1 (Law et al. 1992; Scearce et al. 1993) both heterodimerize with RXR. Interestingly, RXR-NGFI-B/NURR1 and RXR-RAR heterodimers show a similar specificity for direct repeats spaced by 5 nucleotides. However, whereas ligand-dependent RXR activity is inhibited by RAR, NGFI-B and NURR1 promote the transcriptional activation by 9-cis RA or synthetic ligands specific for RXR. Thus, in the presence of NGFI-B or NURR1, direct repeats spaced by 5 nucleotides can serve as specific RXR-responsive elements. Because both NGFI-B and NURR 1 are encoded by immediate-early genes activated by a variety of cell stimulatory signals, our data indicate a novel mechanism for cross talk between retinoid and growth factor signaling pathways. From a physiological point of view, functional interactions between these signaling systems appear logical, as both retinoids and growth factors regulate processes such as cell growth and differentiation (Sporn et al. 1984; Herschman 1991). These observations suggest a number of new possibilities about how growth factors can modulate the diverse actions of retinoids.

\section{Results}

\section{NGFI-B and NURR1 interact with RXR in vivo}

Protein-protein interactions can be detected in yeast by utilizing the two-hybrid system (Fields and Song 1989). This strategy was applied to transfected mammalian cells (human choriocarcinoma JEG-3 cells) to analyze dimeric receptor interactions (Nagpal et al. 1993). In these experiments, hybrid receptors fusing the yeast GAL4 DNA-binding domain to the ligand-binding domain of receptors are expressed in transfected cells either alone or together with a second type of hybrid receptor linked to the potent trans-activation domain of herpes simplex virus VP16 (Fig. 1A). Trans-activation of a luciferase reporter gene containing GAL4-binding sites upstream of a thymidine kinase promoter is only achieved when the coexpressed hybrid receptors can physically interact. Consistent with the finding that RXR forms efficient heterodimers with RAR, GAL4-RXR activates transcription when coexpressed with VP16-RAR (Fig. 1B). In a similar experiment, GAL4-NGFI-B was expressed either alone or together with VP16-RAR or VP16-RXR. Strong activation was detected in the presence of VP16-RXR (Fig. 1B, GAL4-NGFI-B), and in parallel experiments, NURR1 fused to GAL4 was also shown to interact with VP16-RXR (Fig. 1B, GAL4NURR1). GAL4-NURR1 and GAL4-NGFI-B coexpressed with additional derivatives linking the VP16

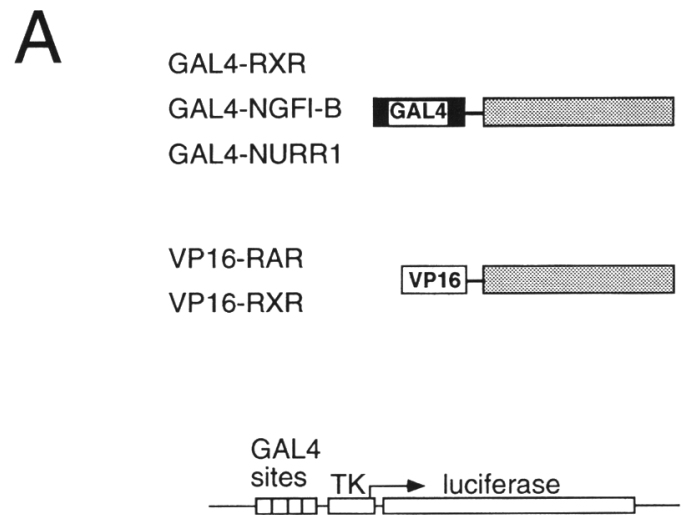

$B$
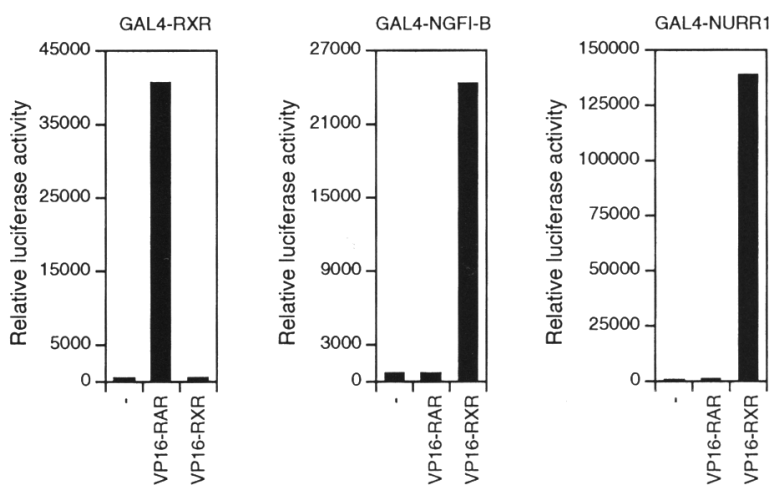

Figure 1. NGFI-B and NURRl interact with RXR in vivo. $(A)$ Receptor derivatives and a luciferase reporter used in the twohybrid transfection experiment in human choriocarcinoma JEG-3 cells. (B) VP16-RXR interacts with GAL4-NGFI-B and GAL4-NURRl in vivo. JEG-3 cells were transfected in duplicate with the GAL4 luciferase reporter and CMX-GAL4-RXR, CMX-GAL4-NGFI-B, or CMX-GAL4-NURR1 alone or together with either CMX-VP16-RAR or CMX-VP16-RXR as indicated, and cell extracts were assayed for luciferase activity.

trans-activation domain to the ligand-binding domains of TR, VDR, and PPAR failed to activate the reporter (data not shown). Comparing trans-activation efficiencies indicated that under these conditions RXR interacted most strongly with NURR1, followed by RAR and NGFI-B. These experiments demonstrate that both NGFI-B and NURR1 can interact with RXR in vivo. Previously, RXR was shown to form homodimers in the presence of its specific ligand 9-cis RA (Zhang et al. 1992b). Such interactions were not detected in these experiments because cells were cultured in the absence of added exogenous ligands. In addition, GAL4-RXR is a potent ligand-dependent trans-activator by itself, which eliminates the possibility to detect RXR homodimers in vivo using this system (data not shown; see also Figure 9, below).

RXR forms heterodimers with NGFI-B/NURR1 that are specific for direct repeats spaced by 5 nucleotides

The results of the experiments shown in Figure 1 
strongly suggested that the formation of heterodimers between RXR and NGFI-B/NURR1 occurred in vivo. To demonstrate heterodimerization we used in vitro gel mobility-shift experiments. Because the relative orientation and spacing between the common half-site AGGTCA was unknown, three different mixtures of differently spaced repeats were used as probes in the initial gel mobility-shift experiment (Fig. 2A). The direct repeat elements ( $\beta R E-m i x ;$ Fig. 2A) are differently spaced variants of the strong RA response element from the RAR $\beta$ gene promoter (GGTTCAccgaaAGTTCA, direct repeat spaced by 5 nucleotides; de Thé et al. 1990; Sucov et al. 1990). When NURR1 and RXR were mixed with the $\beta R E$-elements, the formation of a more slowly migrating complex indicated heterodimeric binding between NURR1 and RXR (Fig. 2B, lane 9|. Because one of the half-sites is related to the NGFI-B/NURR1 monomer binding site (NBRE, AAAGGTCA; Wilson et al. 1991), monomeric binding is detected in the presence of NURR1 alone (Fig. 2B, lane 8). In contrast, no heterodimeric interaction could be detected when RXR and NURR1 were mixed with differently spaced inverted repeats (IR-mix; Fig. 2B). RXR formed weak homodimers when added alone to inverted palindromes [everted repeats (ER-mix); Fig. 2B, lane 4], and addition of NURR1 enhanced binding slightly, suggesting weak heterodimerization on these elements (Fig. 2B, lane 6).

Because heterodimer formation was demonstrated on direct repeats, we determined the preference in binding to individual, differently spaced direct repeat elements of the $\beta R E-m i x$. Therefore, all six $\beta R E$ elements ( $\beta R E$ 1-6) were labeled individually and tested for heterodimer

B
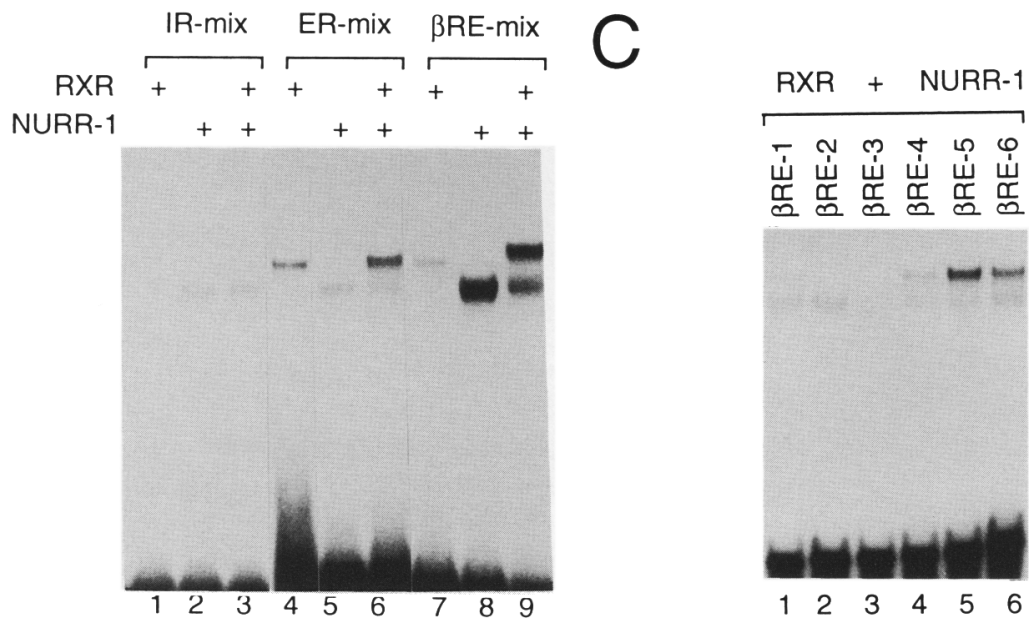

$D$

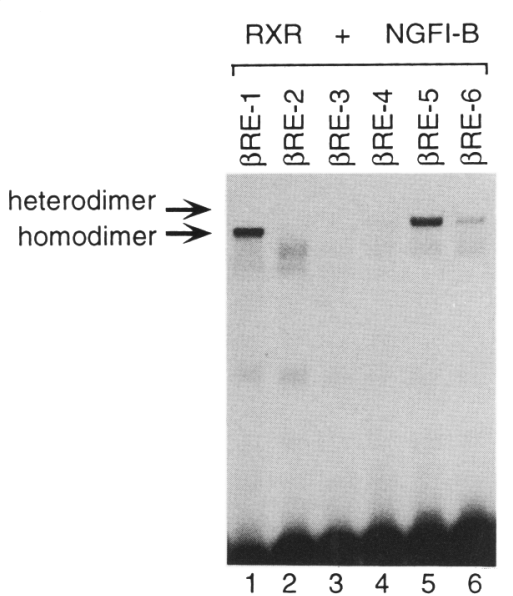

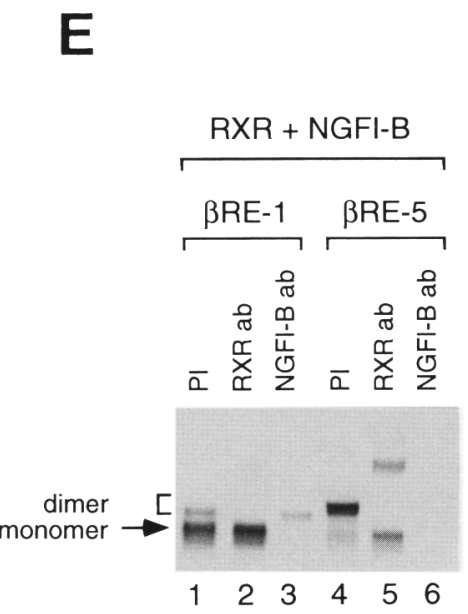

Figure 2. RXR forms heterodimers with NGFI-B and NURR1 that are specific for direct repeats spaced by 5 nucleotides. $(A) \mathrm{Oli}-$ gonucleotide mixtures used in gel mobilityshift assays. The IR-mix, ER-mix, and $\beta R E-$ mix consist of oligonucleotides with 1-6 nucleotides between the conserved halfsites, respectively. (B) Human RXR $\alpha$ (RXR) and NURR1, derived from in vitro translation in rabbit reticulocyte lysates, were mixed and assayed in gel mobility-shift assays together with IR-mix, ER-mix, or $\beta$ REmix as ${ }^{32} \mathrm{P}$-labeled probes as indicated. $(C)$ RXR-NURR 1 heterodimers are specific for direct repeats spaced by 5 nucleotides. RXR and NURR1, derived from in vitro translation in reticulocyte lysates, were mixed with individual ${ }^{32} \mathrm{P}$-labeled $\beta R E$ variants (direct repeats) spaced by 1-6 nucleotides. (D) RXR-NGFI-B heterodimers are specific for direct repeats spaced by 5 nucleotides. RXR and NGFI-B, derived from in vitro translation in reticulocyte lysates were mixed with ${ }^{32} \mathrm{P}$-labeled $\beta R E$ variants (direct repeats) spaced by 1-5 nucleotides. $(E) \mathrm{Re}$ ceptor identity on direct repeats spaced by 1 or 5 nucleotides. RXR and NGFI-B, derived from in vitro translation in reticulocyte lysates were mixed with ${ }^{32}$ P-labeled $\beta R E-1$ (lanes 1-3) or $\beta B E-5$ (lanes 4-6). Preimmune serum (lanes 1,4), antiserum against RXR (lanes 2,5), or NGFI-B (lanes 3,6) were included in the reactions. The positions of monomers and dimers are indicated. 
binding. As demonstrated in Figure $2 \mathrm{C}$, the RXRNURR1 heterodimer showed a clear specificity for the natural direct repeat spaced by 5 nucleotides ( $\beta R E-5$, lane 5). In parallel experiments, RXR-NGFI-B heterodimers were also shown to preferentially recognize direct repeats spaced by 5 nucleotides (Fig. 2D, lane 5). Lower salt concentrations were used in the binding buffer in these experiments, and under these conditions RXR homodimer binding was detected on direct repeats spaced by 1 nucleotide as evident from the slowly migrating band seen when RXR was added alone (Fig. 2D, lane 1). Therefore, antibodies against RXR or NGFI-B were used in the binding reactions to confirm the identity of the receptors in the dimeric complexes (Fig. 2E).

We then tested the ability of the RXR-NURR1 heterodimer to recognize differently organized and previously characterized HREs (Fig. 3A; see legend). These experiments confirmed the preference for heterodimeric binding to the $\beta R E$ (Fig. 3B, lane 12). In addition, we used a set of direct repeats that are unrelated to the $\beta R E$ within the spacer sequence to confirm that the preference in
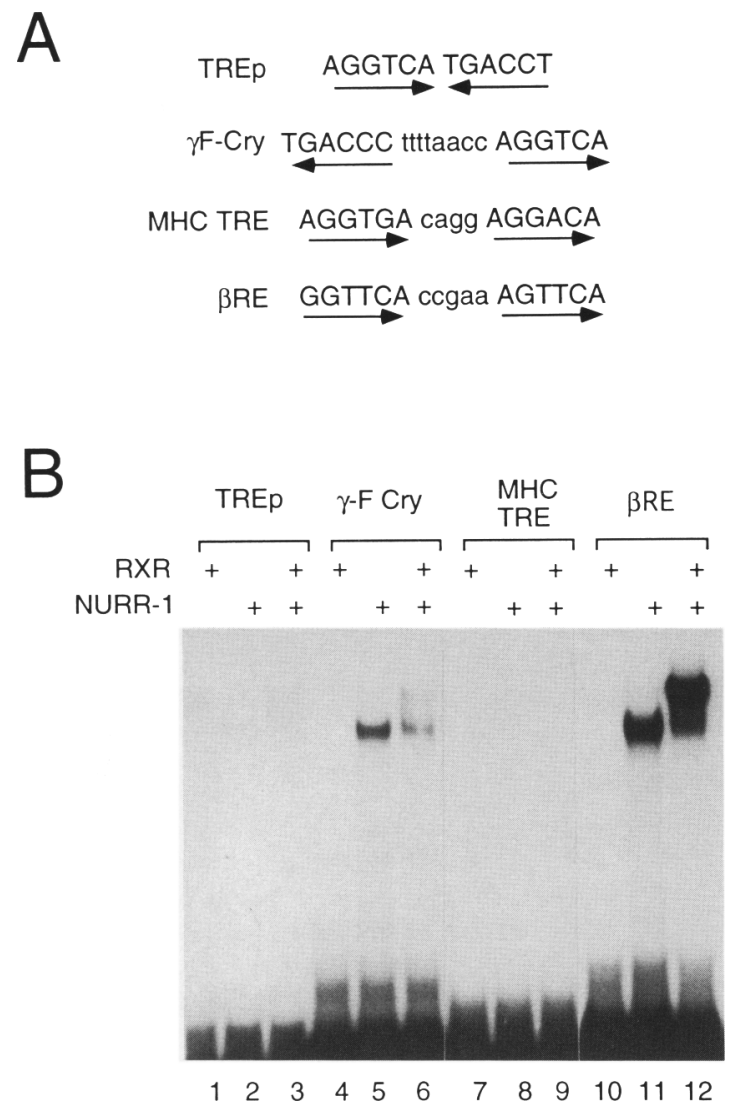

Figure 3. RXR-NURR1 heterodimers are selective for the $\beta R E$. (A) RXR-NURR1 heterodimerization was tested on TREp (Umesono et al. 1988), the RA response element from the $\gamma \mathrm{F}$ Cry (Tini et al. 1993), the thyroid HRE from the myosin heavy chain gene (MHC TRE; Glass et al. 1989), and the RA response element from the human RAR $\beta$ gene promoter $\left(\beta R E_{;}\right.$de The et al. 1990; Sucov et al. 1990).
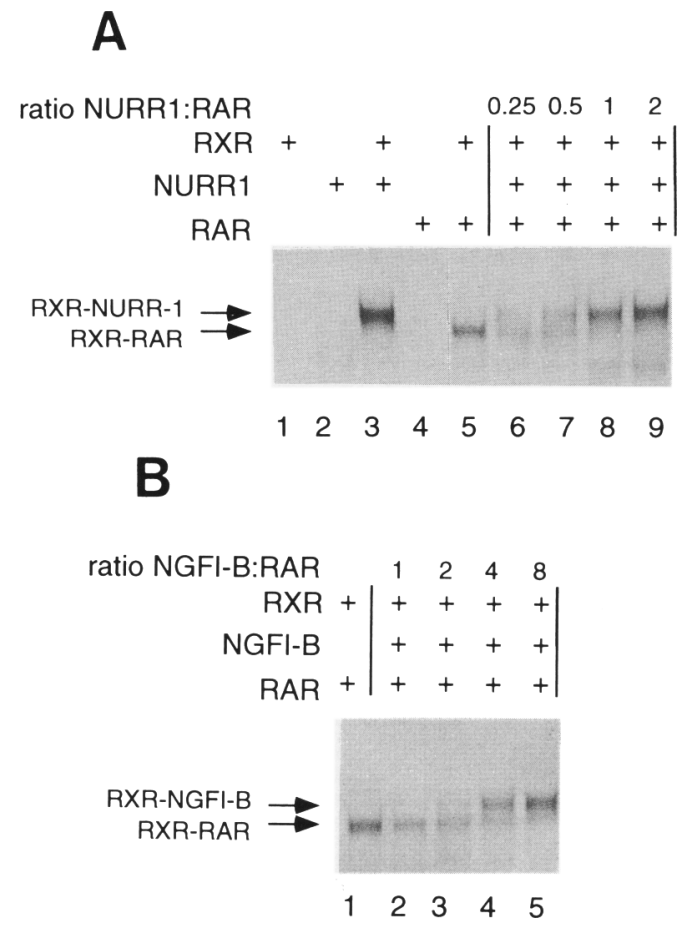

Figure 4. Heterodimer DNA-binding affinity. $(A)$ NURR1 was mixed either alone (lane 2), with RXR (lane 3), or together with $\mathrm{RXR}$ and RAR at the ratios indicated (lanes $6-9$ ). The positions of the RXR-NURR1 and the RXR-RAR complexes are indicated. $(B)$ NGFI-B was mixed with RXR and RAR at the ratios indicated. The positions of the RXR-NGFI-B and RXR-RAR complexes are indicated.

binding was the result of spacer length rather than sequence (data not shown). We conclude that both NURR1 and NGFI-B are able to form heterodimers with RXR and that these heterodimeric complexes preferentially bind direct repeats spaced by 5 nucleotides.

An interesting feature of RXR-NGFI-B/NURR1 heterodimers is the similar preference for direct repeats spaced by 5 nucleotides, as was established previously, as the optimal binding site for RXR-RAR heterodimers (Yu et al. 1991, Hermann et al. 1992; Kliewer et al. 1992b; Mader et al. 1993a; Perlmann et al. 1993). We therefore compared the relative binding efficiency for heterodimeric complexes interacting with the $\beta R E$ element. In these experiments, RAR and RXR were mixed with increasing amounts of NURR 1 or NGFI-B and analyzed in gel mobility-shift assays. At a NURR1/RAR ratio of 0.5 or more, NURR 1 competes efficiently as indicated by the formation of the more slowly migrating RXR-NURRI complex and the gradual disappearence of the RXR-RAR band (Fig. 4A, lanes 6-9). In a similar experiment, NGFI-B was shown to compete but at a higher NGFI-B/RXR ratio (Fig. 4B, lanes 2-5). These experiments are in good agreement with the results from the two-hybrid experiment (Fig. 1) and indicate binding affinities that are two- to fourfold higher for RXR- 
NURR1 and two- to threefold lower for RXR-NGFI-B compared with RXR-RAR heterodimers.

\section{RXR-NGFI-B/NURR1 heterodimers bind with a fixed polarity to direct repeats spaced by 5 nucleotides}

The asymmetric nature of direct repeats raises the question as to the $5^{\prime} \rightarrow 3^{\prime}$ polarity of subunits bound to such elements. Previous data demonstrated that RXR-RAR or RXR-TR heterodimers show a preferred polarity with RXR bound in the $5^{\prime}$ half-site and RAR and TR in the $3^{\prime}$ half-site of cognate direct repeats (Kurokawa et al. 1993; Perlmann et al. 1993; Zechel et al. 1994a). To determine the polarity of the RXR-NGFI-B/NURR1 heterodimers, we used two variants of a synthetic element (NX 3', NX $5^{\prime}$; Fig. 5A). These are direct repeats spaced by 5 nucleotides having optimal NGFI-B/NURR1 (NBRE) monomer-binding sites in the $3^{\prime}$ and $5^{\prime}$ position, respectively. Efficient heterodimeric binding is seen only when the NBRE is in the $3^{\prime}$ position demonstrating a fixed polarity with RXR in the 5' position and NURR1 in the 3' position of the direct repeats. In contrast, because both repeats contain one copy of the NBRE, monomeric binding

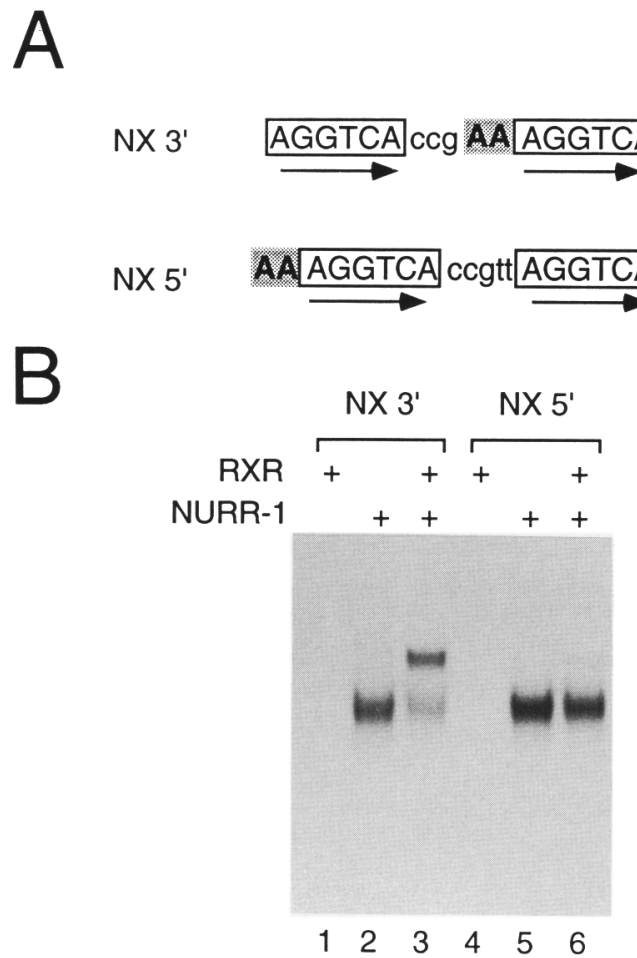

Figure 5. RXR-NGFI-B/NURR1 heterodimers bind with a fixed polarity to direct repeats spaced by 5 nucleotides. $(A)$ Two different elements composed of direct repeats spaced by $5 \mathrm{nu}$ cleotides that contain the previously defined NGFI-B monomer binding site (NBRE) in either the $3^{\prime}\left(\mathrm{NX} 3^{\prime}\right.$ ) or in the $5^{\prime}$ position (NX 5'), respectively, were tested as binding sites for the RXRNURR1 heterodimer. (B) Human RXR $\alpha$ (RXR) and NURR1, derived from in vitro translation in reticulocyte lysates, were mixed either alone or together, with ${ }^{32}-\mathrm{P}$ labeled NX $3^{\prime}$ or NX 5 as indicated. was detected with both elements (Fig. 5B, lanes 2,5). The identical results were seen when analyzing RXRNGFI-B heterodimers on these binding sites (data not shown). Because the results demonstrate a strict polarity in DNA binding, the data emphasize the generality in the mechanism of heterodimeric DNA binding.

The carboxy-terminal domains of NGFI-B and NURR1 contain critical dimerization interfaces

In several receptors an important dimerization interface has been localized to the carboxy-terminal ligand-binding domains (Forman et al. 1989; Glass et al. 1989; Yu et al. 1991; Kliewer et al. 1992a; Leid et al. 1992; Marks et al. 1992; Au-Fliegner et al. 1993). To determine whether the putative ligand-binding domains of NURRl and NGFI-B are important for their heterodimerization with RXR, carboxy-terminally truncated derivatives of NURR1 and NGFI-B (NURR1 355 and NGFI-B 414, respectively/ were used in gel mobility-shift experiments employing the $\beta R E$ or the monomeric NGFI-B/NURR1binding site NBRE (Fig. 6A). As demonstrated in Figure $6, \mathrm{~B}$ and $\mathrm{C}$, heterodimeric, but not monomeric, DNA binding required the intact carboxy-terminal domains of both NURR1 and NGFI-B. These data define a function for the NGFI-B/NURR 1 carboxy-terminal domains and further emphasize the conservation of the mechanism of heterodimeric complex formation.

\section{NGFI-B and NURR1 modulate RA signaling}

Both the RXR-NGFI-B/NURR1 and RXR-RAR heterodimers have similar specificities for binding to direct repeats spaced by 5 nucleotides. This similarity suggests that NGFI-B and NURR1 modulate genes containing such RA response elements. This was tested in in vivo transfection experiments. For this purpose a luciferase reporter containing a single copy of the $\beta R E$ upstream of a thymidine kinase promoter was transfected into choriocarcinoma JEG-3 cells either alone or together with expression vectors encoding NGFI-B or NURR1 (Fig. 7A). In the absence of any cotransfected receptors, the reporter was activated about sevenfold in response to $1 \mu \mathrm{M}$ all-trans RA (because of endogenous RXR and RAR in these cells; Sugawara et al. 1993). Interestingly, cotransfection of either NGFI-B or NURRI resulted in a dramatic increase of RA responsiveness (Fig. 7A). The carboxy-terminally truncated NGFI-B and NURR1 that were unable to promote in vitro heterodimerization (Fig. 6A, NGFI-B 414 and NURR1 355) also failed to promote efficient induction of the $\beta R E$ reporter (Fig. 7A). Furthermore, cotransfection of expression vectors for NGFI-B and RXR resulted in a further increase in trans-activation from the $\beta R E$ reporter (data not shown). The stimulation is specific for the $\beta R E$ element because NGFI-B and NURR1 did not stimulate transcripton from a single copy of the RA-responsive synthetic inverted repeat element (TREp; Umesono et al. 1988; Fig. 7A) or the 
Figure 6. The carboxy-terminal domain of NGFI-B and NURR 1 contains a critical dimerization interface. $(A \mid$ Wild-type receptors, carboxy-terminally truncated receptor derivatives, and response elements used in in vitro gel mobility-shift experiments. (B) Human RXR $\alpha$ (RXR), NURR1, and NURR1 355, derived from in vitro translation in reticulocyte lysates were mixed with ${ }^{32} \mathrm{P}$-labeled $\beta R E$ or NBRE as indicated. (C) RXR, NGFI-B, and NGFI-B 414 , derived from in vitro translation in reticulocyte lysates, were mixed with ${ }^{32} \mathrm{P}$ labeled $\beta$ RE or NBRE as indicated.

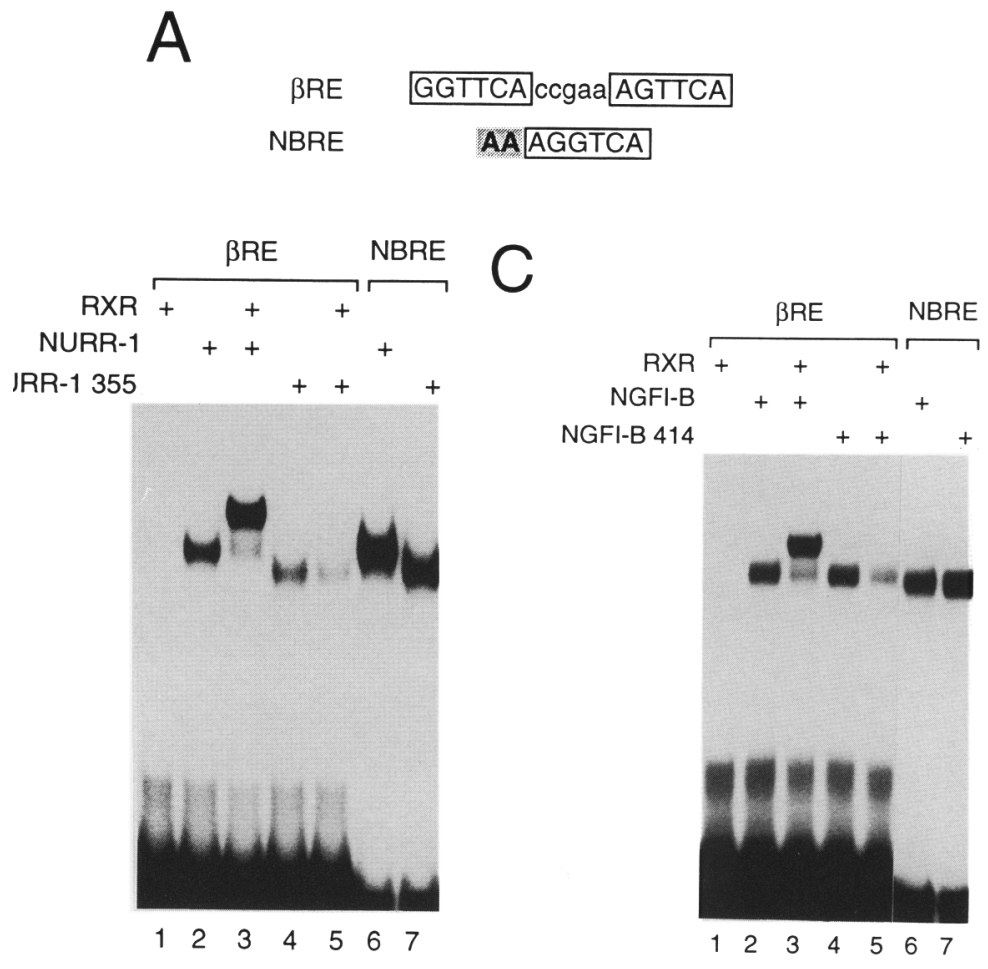

everted repeat RA-response element in the $\gamma \mathrm{F}$-crystalline gene ( $\gamma$ F-Cry; Tini et al. 1993; Fig. 7A). In addition, in agreement with in vitro data, a reporter containing one copy of NX $3^{\prime}$ but not NX $5^{\prime}$ is activated in response to $1 \mu \mathrm{M}$ RA in the presence of either NURR1 or NGFI-B (Fig. 7B). Transfection of a reporter containing two copies of the NX $3^{\prime}$ resulted in a dramatic increase in luciferase activity when either NGFI-B or NURR 1 was coexpressed and cells were incubated in the presence of $1 \mu \mathrm{M}$ RA (Fig. $7 \mathrm{C}$. Consistent with the previous finding that NGFI-B can constitutively activate transcription, the basal reporter activity was increased by NGFI-B or NURR 1 in the absence of added ligands (Fig. 7C; Davis et al. 1991; Wilson et al. 1991). We confirmed that the observed activation was attributed to RXR by using a dominantnegative RXR derivative $(\mathrm{mRXR} \alpha \mathrm{dn}$ ) described previously that lacks the ability to respond to 9-cis RA (Durand et al. 1992). When this derivative, but not wild-type RXR, was coexpressed with NGFI-B or NURR1, activation was efficiently blocked (Fig. $7 \mathrm{C}$ ). These data are consistent with our in vitro data and indicate RXR-NGFI$\mathrm{B} / \mathrm{NURR} 1$ heterodimerization as the underlying basis for the enhancement of RA responsiveness.

$R X R$ can be activated in complex with NGFI-B/NURR1 but not with RAR

The dramatic increase in RA responsiveness was observed at nonphysiological levels of all-trans RA $(1 \mu \mathrm{M}$ RA; Fig. 7A). We therefore wished to test whether the effect was sensitive to the concentration of added all- trans RA. As shown in Figure 8A, lower levels of alltrans RA ( $10 \mathrm{nM})$ were insufficient to achieve the activation mediated by NGFI-B/NURR1, whereas these levels induced the full activation mediated through endogenous receptors (Fig. 8A). In contrast, increasing amounts of cotransfected NGFI-B expression vector inhibit the $\beta R E$ reporter in response to $10 \mathrm{nM}$ RA (Fig. 8B). Taken together, our data indicate that the effect of NGFI-B/ NURR 1 is mediated by a RA metabolite such as 9-cis RA rather than all-trans RA itself (Heyman et al. 1992; Levin et al. 1992; Allenby et al. 1993). At intermediate levels of added ligands ( $25 \mathrm{nM}$ ), 9-cis RA but not all-trans RA was shown to promote the maximal NGFI-B/NURRl activation of the $\beta R E$ reporter (data not shown). Thus, the RXR-NGFI-B/NURR 1 and RXR-RAR heterodimers mediate retinoid responses that are pharmacologically distinct.

To analyze the pharmacological properties of RXRNGFI-B/NURR1 heterodimers in further detail, we used synthetic retinoids described previously that are specific for either RAR or RXR (TTNPB and SR11237, respectively; Mangelsdorf et al. 1990; Lehmann et al. 1992). As shown in Figure 9A, at $0.1 \mu \mathrm{M}$ TTNPB and $1 \mu \mathrm{M}$ SR11237, activation of the GAL4 luciferase reporter by either GAL4-RXR or GAL4-RAR was highly specific. Interestingly, cotransfection of GAL4-RXR and wildtype RAR inhibits the response to SR 11237 and promotes activation by TTNPB (Fig. 9B). In contrast, NGFI-B (Fig. 9B) or NURR1 (data not shown) does not block the SR11237 response. These data are in accordance with previous results using synthetic retinoids and indicate that the RXR-RAR heterodimer is prefer- 
RXR-NGFI-B/NURR1 heterodimers

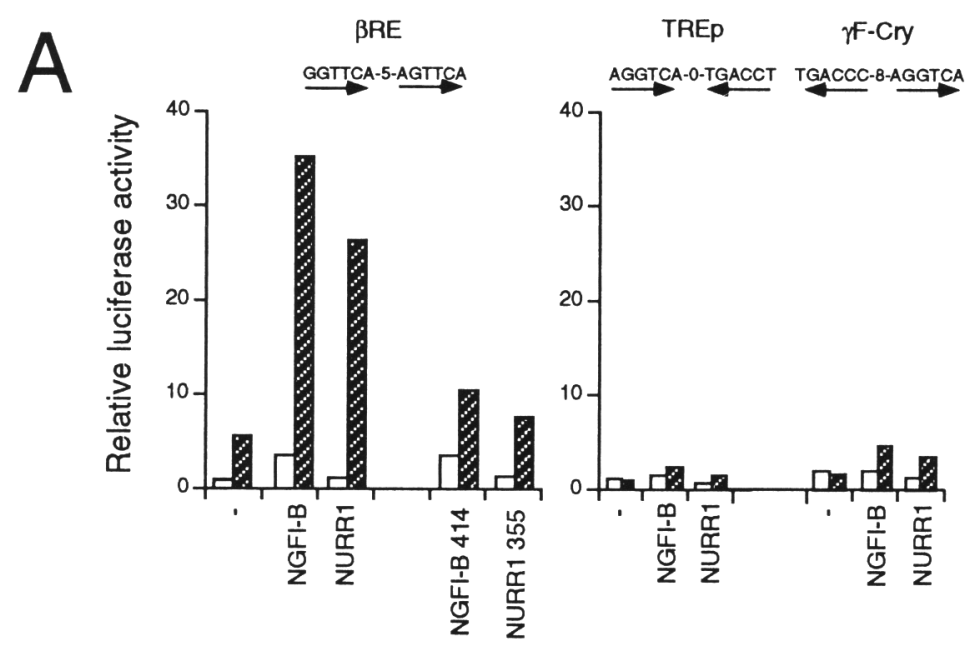

B
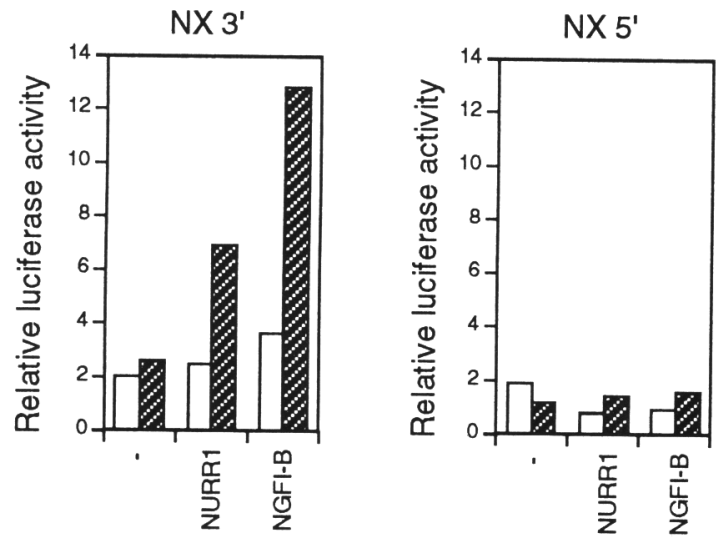

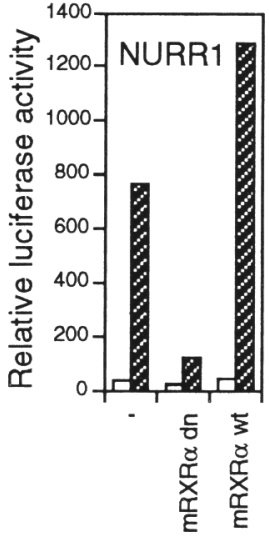

Figure 7. NGFI-B and NURR1 modulate retinoid signaling. $(A)$ Human JEG-3 cells were transfected in duplicate with a luciferase reporter containing single copies of the $\beta$ RE, TREp, or $\gamma$ F-Cry HREs either alone or together with NGFI-B, NURR1, NGFI-B 414 ( $\beta$ RE only), or NURRI 355 ( $\beta R E$ only) and treated with either ethanol (open bars) or $1 \mu \mathrm{M}$ all-trans RA (hatched bars) as indicated. Cell extracts were subsequently assayed for luciferase activity. (B) JEG-3 cells were transfected in duplicate with luciferase reporters containing single copies of the NX $3^{\prime}$ or NX $5^{\prime}$ HRE either alone or together with NGFI-B or NURR1 and treated with either ethanol (open bars) or $1 \mu \mathrm{M}$ all-trans RA (hatched bars) as indicated. Cell extracts were assayed for luciferase activity. (C) JEG-3 cells were transfected in duplicate with a luciferase reporter containing two copies of the NX $3^{\prime}$ HRE. The reporter was transfected either alone, together with NGFI-B or NURR1, or with NGFI-B and NURR1 cotransfected with either a dominant-negative mRXR $\alpha$ derivative (Durand et al. 1992) or with wild-type mouse RXR $\alpha$. Cells were treated with either ethanol (open bars) or $1 \mu \mathrm{M}$ all-trans RA (hatched bars) as indicated. Cell extracts were assayed for luciferase activity.

entially activated through the RAR subunit (Lehmann et al. 1992; Kurokawa et al. 1994; see Discussion). Furthermore, our data suggest that in contrast to RAR, NGFI-B heterodimerization with RXR does not block the activation by SR 11237.

To further substantiate this finding and to assess the significance of these data, synthetic retinoids were used with wild-type receptors in transfection experiments. As shown in Figure 10A, a reporter containing two copies of the NX 3' element is activated by RAR alone or together with RXR in response to TTNPB (Fig. 10A). Interestingly, NGFI-B or NURRl expression results in a shift in ligand specificity because SR11237 rather than TTNPB leads to efficient activation of the reporter (Fig. 10A). The reporter is weakly activated also by RXR in response to SR11237, presumably through the formation of RXR homodimers binding to this element (Fig. 10A; Zhang et al. 1992b). Finally, in a similar experiment, a reporter containing three copies of the $\beta R E$ was shown to behave similarly (Fig. 10B). Thus, cotransfection of NGFI-B resulted in efficient activation by SR11237. In contrast, without cotransfected receptors or with RAR, this reporter responds efficiently to TTNPB but not to SR11237. In conclusion, our data show that both the RXR-RAR and RXR-NGFI-B/NURR1 heterodimers bind similar direct repeats spaced by 5 nucleotides, but 
$A$
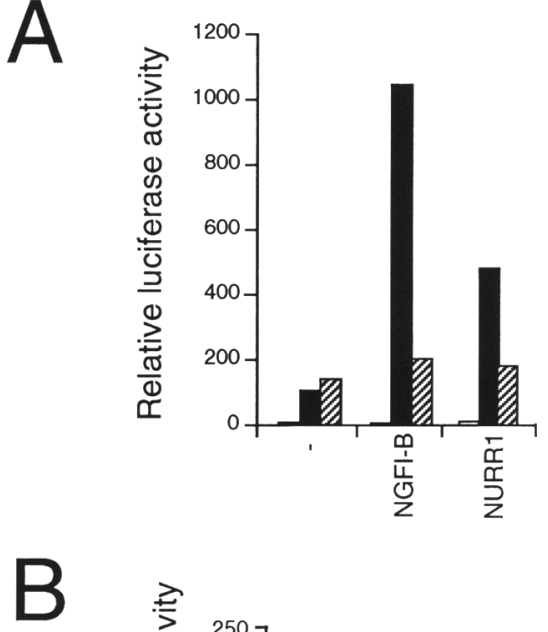

switching it between an inactive and an active heterodimerization partner. It appears likely that other nuclear receptors are also able to shift RXR into an active partner thus defining a novel class of receptors that can serve as cofactors for RXR.

The observations reported here have at least two possible consequences for retinoid signaling. First, it has been demonstrated previously that 9-cis RA activates RXR homodimers binding preferentially to response elements composed of direct repeats spaced by 1 nucleotide (Mangelsdorf et al. 1991; Zhang et al. 1992b). NGFI-B and NURR 1 can increase the potential of RXR to modulate gene expression in a ligand-dependent manner by allowing direct repeats spaced by 5 nucleotides to serve as specific RXR response elements. Second, NGFI-B and NURR1 are encoded by immediate-early
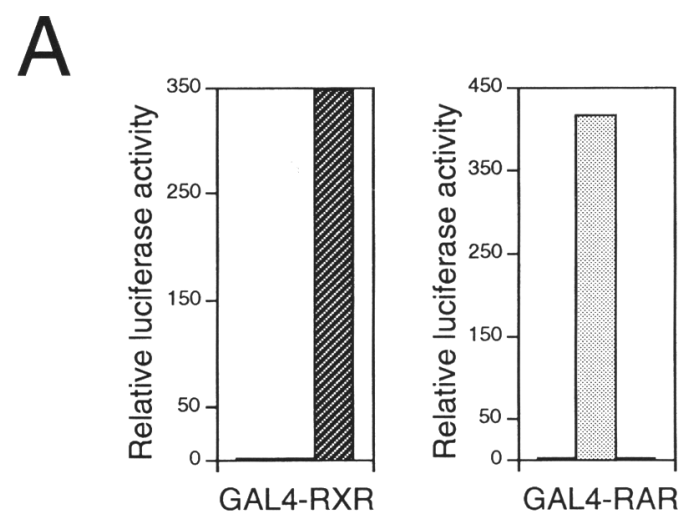

all-trans RA. (A) NGFI-B and NURR1 promote transcriptional activation in the presence of $1 \mu \mathrm{M}$ but not $10 \mathrm{nM}$ all-trans RA. JEG-3 cells were transfected in duplicate with a luciferase reporter containing a single copy of the $\beta R E$ either alone or together with NGFI-B or NURR 1 and treated with either ethanol (open bars), $1 \mu \mathrm{M}$ all-trans RA (solid bars), or $10 \mathrm{nM}$ all-trans RA (hatched bars) as indicated. Cell extracts were assayed for luciferase activity. (B) NGFI-B can compete with endogenous receptors and block transcriptional activation from a $\beta R E$. JEG-3 cells were transfected in duplicate with a luciferase reporter containing a single copy of the $\beta R E$ either alone or together with CMX-NGFI-B at 50, 100, or $200 \mathrm{ng}$ as indicated and treated with either ethanol (open bars) or $10 \mathrm{nM}$ all-trans RA (hatched bars) as indicated.

only the latter can be activated through the RXR subunit of the complex.

\section{Discussion}

In this study we show that two orphan receptors, NGFI-B and NURR1, can form heterodimers with RXR that are efficiently activated by ligands binding to RXR. In contrast, RXR-RAR heterodimers are only activated through the RAR subunit. Thus, these findings demonstrate the existence of a novel mechanism whereby RAR and NGFI-B/NURR1 have an opposite effect on RXR,
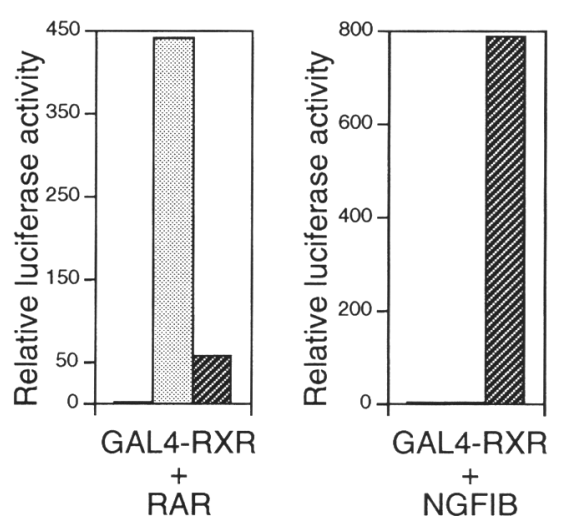

Figure 9. RAR but not NGFI-B inhibits ligand activation by GAL4-RXR. (A) TTNPB and SR11237 specifically activate GAL4-RXR and GAL4-RAR, respectively. JEG-3 cells were transfected in duplicate with a GAL4 luciferase reporter and CMX-GAL4-RXR or CMX-GAL4-RAR and treated with ethanol (no ligand), $0.1 \mu \mathrm{M}$ TTNPB (stippled bar), or with $1 \mu \mathrm{M}$ SR1 1237 (hatched bar). Cell extracts were assayed for luciferase activity. (B) JEG-3 cells were transfected in duplicate with a GAL4 luciferase reporter and CMX-GAL4-RXR together with either CMX-RAR or CMX-NGFI-B and treated with ethanol (no ligand), $0.1 \mu \mathrm{M}$ TTNPB (stippled bar), or with $1 \mu \mathrm{M}$ SR1 1237 (hatched bars). Cell extracts were assayed for luciferase activity. 

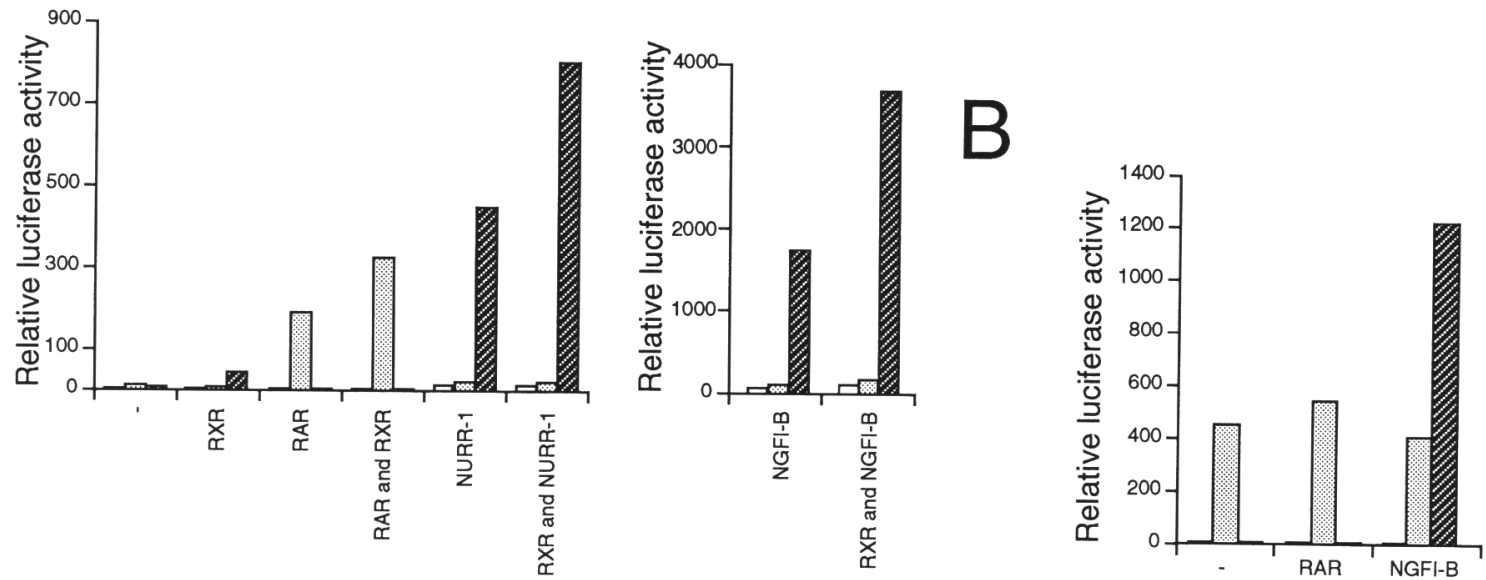

Figure 10. NGFI-B and NURRl promote ligand-dependent activation through RXR. (A) JEG-3 cells were transfected in duplicate with a luciferase reporter containing two copies of the NX 3' HRE alone or with expression vectors for the indicated receptors and treated with ethanol (open bars), $0.1 \mu \mathrm{M}$ TTNPB (stippled bars); or with $1 \mu \mathrm{M}$ SR 11237 (hatched bars). Cell extracts were assayed for luciferase activity. (B) JEG-3 cells were transfected in duplicate with a luciferase reporter containing two copies of the $\beta$ RE HRE alone or with RAR or NGFI-B and treated with ethanol (open bars), $0.1 \mu \mathrm{M}$ TTNPB (stippled bars), or with $1 \mu \mathrm{M}$ SR11237 (hatched bar). Cell extracts were assayed for luciferase activity.

genes. Thus, the interaction with RXR suggests a mechanism whereby growth factors could affect retinoid signaling as well as modulating the pharmacological properties of responding cells.

\section{$D N A$-binding properties of the NGFI-B/NURR1-RXR heterodimer}

The ability of NGFI-B and NURR1 to heterodimerize with RXR is shared with other nuclear receptors including RAR, TR, the vitamin $\mathrm{D}$ receptor, and the peroxisome proliferator-activated receptor (Yu et al. 1991; Bugge et al. 1992; Kliewer et al. 1992a,b; Leid et al. 1992; Marks et al. 1992; Zhang et al. 1992a). Several features of RXR-NGFI-B/NURR1 heterodimerization resemble those of heterodimers characterized previously. Other RXR heterodimers have been shown to form in solution in the absence of specific DNA-binding sites (Yu et al. 1991; Bugge et al. 1992; Kliewer et al. 1992a,b; Leid et al. 1992; Marks et al. 1992). Similarly, NGFI-B and NURR1 fused to GAL4 interact with VP16-RXR in the two-hybrid transfection experiment (Fig. 1), indicating that RXR-NGFI-B/NURRl heterodimers are also able to form in solution in the absence of cognate HREs. Second, RXR-RAR and RXR-TR heterodimers interact with cognate direct repeats with a fixed polarity. Our data show that RXR-NGFI-B/NURR1 heterodimers bind to direct repeats spaced by 5 nucleotides with a similar polarity (RXR in the $5^{\prime}$ half-site). By analogy with RXR-RAR and RXR-TR heterodimers, the observed polarity is most likely the result of protein-protein interactions between the DNA-binding domains of RXR and NGFI-B/NURR1 (Mader et al. 1993b; Perlmann et al. 1993; Towers et al. 1993; Zechel et al. 1994a,b). Finally, similar to RAR, TR and other dimerizing receptors, carboxy-terminally truncated derivatives of NGFI-B and NURR1, failed to het- erodimerize with $\mathrm{RXR}$, indicating the presence of a dimerization interface within the carboxy-terminal domain. These observations suggest that the mechanism of dimerization and DNA binding is highly conserved between several receptors forming heterodimers with RXR.

Both NGFI-B and NURR1 have been shown to bind with high affinity to monomeric binding sites (Wilson et al. 1991, 1993b; Scearce et al. 1993). Thus, an intriguing feature of these receptors is that they can bind both as monomers and heterodimers to DNA. The DNA-binding properties of NGFI-B and NURR1 apparently resemble those of TR, because this receptor also interacts efficiently with DNA both as a monomer and dimer (Andersson et al. 1992; Forman et al. 1992; Katz and Koenig 1993; Miyamoto et al. 1993; Schräder et al. 1994a). Several orphan receptors such as RevErbA, ROR, ELP, SF-1, and its Drosophila homolog FTZ-F1 bind as monomers to extended single half-sites, and it may be speculated that some of these may also belong to this category of monomer/dimer binding receptors (Ueda et al. 1992; Harding and Lazar 1993; Wilson et al. 1993b; Giguere et al. 1994). Accordingly, the DNA-binding properties of NGFI-B, NURRl, and TR may serve as a paradigm for a broader class of nuclear receptor-DNA interactions.

\section{NGFI-B/NURR1 as modulators of retinoid signaling}

Our data show that NGFI-B and NURR1 promote efficient RA activation through the $\beta$ RE in JEG-3 cells. Although NGFI-B and NURR1 also could promote reporter activation in the absence of retinoids, the effect was moderate compared to the activity induced by retinoids (Figs. 7C, 10A; Davis et al. 1991; Wilson et al. 1991). Our conclusion that the transcriptional enhancement is the result of heterodimerization between NGFI-B/ 
NURR1 and RXR is based on a number of observations. Consistent with in vitro DNA-binding data, the stimulatory effect is specific for the $\beta R E$ and was not observed when using other reporter constructs containing differently organized HREs. Furthermore, the NX $3^{\prime}$ element promoted both heterodimerization as well as transcriptional activation, whereas the NX 5 ' element did not. In addition, carboxy-terminally truncated derivatives of NGFI-B and NURR 1 that fail to heterodimerize with RXR in vitro, were unable to promote transcriptional activation in vivo. Finally, the effect is mediated by 9-cis RA (data not shown) or the RXR-specific ligand SR11237 but not by all-trans RA or TTNPB, indicating that RXR and not RAR mediates the enhancement. It should be noted that NGFI-B consistently promotes activation more efficiently compared with NURR1 although in vitro data indicate that NURRl heterodimerizes more strongly with RXR. We do not know whether this lack of correlation is the result of higher expression levels of NGFI-B in transfected cells, increased efficiency of the wild-type receptors to heterodimerize in vivo, or to a higher trans-activation capacity of the RXR-NGFI-B complex. In any event, our data strongly support RXRNGFI-B/NURR 1 heterodimerization as the underlying basis for the observed transcriptional activation.

Previous studies using synthetic ligands specific for either RXR or RAR have indicated that RXR-RAR heterodimers bound to direct repeats spaced by 5 nucleotides are nonresponsive to ligands acting through the RXR subunit (Lehmann et al. 1992; Kurokawa et al. 1994).

Kurokawa et al. (1994) demonstrated that the $5^{\prime} \rightarrow 3^{\prime}$ polarity of RXR-RAR heterodimers is a critical determinant for ligand specificity. In their experiments, the receptor binding to the $3^{\prime}$ half-site serves as the activating subunit of the complex. In addition, Schräder et al. (1994b) described a similar relationship involving TRVDR heterodimers. In this respect, RXR-NGFI-B/ NURR1 heterodimers are functionally distinct, because RXR can activate when binding to the $5^{\prime}$ half-site of a direct repeat spaced by 5 nucleotides. The data predict that RXR adapts different conformations depending on the identity of its heterodimerization partner. Therefore, although no strict polarity rules can be deduced from all of these data, heterodimerization and specific DNA binding is clearly emerging as a powerful mechanism for allosteric regulation of ligand-dependent receptor activation.

In addition to RAR, NGFI-B, and NURR1, another orphan receptor, MB67, was recently shown to form RXR heterodimers that can constitutively activate transcription from direct repeats spaced by 5 nucleotides (Baes et al. 1994). This would predict that variable expression levels of RAR, RXR, NGFI-B, NURR1, and MB67 would allow multiple regulatory readouts from genes containing $\beta R E$-like sequences. Taken together, all of these data indicate that $\beta R E$-like elements serve as junction points for retinoid signaling, allowing complex combinatorial interactions between several different regulators and ligands.

\section{Convergence of growth factor and retinoid signaling}

Previously, substantial hormonal cross talk between divergent signaling pathways became evident from the discovery that the growth factor regulated transcription factor AP-1 can modulate the activity of RAR, as well as several other nuclear receptors (Schüle et al. 1991; Yang Yen et al. 1991; for review, see Pfahl 1993). In most cases, AP-1 antagonizes nuclear receptors through a mechanism involving weak protein-protein interactions occurring independently of specific DNA binding. In contrast, the agonistic effect mediated through RXRNGFI-B/NURR1 heterodimerization is apparently dependent on the interaction with specific direct repeat HREs. Interestingly, this mechanism resembles the AP-1 regulation of the proliferin gene characterized previously, which can be both positively and negatively regulated by glucocorticoids and AP-I depending on its subunit composition (Diamond et al. 1990; Miner and Yamamoto 1991; Pearce and Yamamoto 1993). In the proliferin gene, a so-called "composite" response element mediates signaling by both glucocorticoids and AP1. By analogy to such elements, direct repeats spaced by 5 nucleotides may allow divergent signals to coordinately modulate gene expression in a more selective manner than would be the case if the regulation was entirely independent of specific DNA binding. In conclusion, our data demonstrating RXR-NGFI-B/NURR1 heterodimerization along with the previously characterized cross talk with AP-1 underscore a requirement for alternative and functionally distinct mechanisms for convergence between retinoid and growth factor signaling systems.

As would be expected from a physiological viewpoint, several cases of cross talk between retinoid and growth factor signaling have been reported previously. For example, by inhibiting cell growth and promoting differentiation, retinoids have been shown to oppose the effects of extracellular signals that stimulate cell proliferation. Furthermore, retinoids inhibit the negative selection through apoptosis of self-reactive thymocytes (Iwata et al. 1992; Yang et al. 1993). These effects could be explained, in principle, by AP-1-retinoid receptor antagonism. On the other hand, consistent with the data shown here, several cases of synergism between retinoids and growth factors have also been reported. Examples include the control of gene expression, cell differentiation, and the promotion of embryonic neuronal survival (Cho and De Robertis 1990; Hendry and Belford 1991; Li and Sartorelli 1992; Kurie et al. 1993; Kent et al. 1994). It will be interesting in future studies to address the extent to which NGFI-B and NURR1 participate in these and/or other regulatory events controlled by both retinoid- and growth factor-mediated signaling pathways.

\section{Materials and methods}

Plasmids

CMX-GAL4-RXR, CMX-GAL4-NGFI-B, and CMX-GAL4NURR1 contain sequences encoding the GAL4 DNA-binding 
domain (amino acids 1-147; Sadowski and Ptashne 1989) followed by sequences encoding the human $\operatorname{RXR} \alpha$, amino acids 224-462 (Mangelsdorf et al. 1990), NGFI-B, amino acids 348597 (Milbrandt 1988), and NURR1, amino acids 353-598 (Law et al. 1992), respectively, cloned in PCMX expression vector (Umesono et al. 1991). CMX-VP16-RAR and CMX-VP16-RXR contain the herpes simplex VP16 trans-activation domain (Perlmann et al. 1993) followed by the complete coding sequences of human RAR $\alpha$ (Giguere et al. 1987) and human RXR $\alpha$, respectively. CMX-NURR1 and CMX-NGFI-B contain NURR1 and NGFI-B cDNA sequences cloned into pCMX. CMX-NURRl 355 and CMX-NGFI-B 414 contain sequences encoding truncated NURR1 (amino acids 1-355) and NGFI-B (amino acids 1-414), respectively. The RXR dominant negative is derived from mouse $\operatorname{RXR} \alpha$ and truncated at amino acid 448 (Durand et al. 1992). Reporter plasmids contain one, three, or four copies of the indicated HREs (see figure legends) upstream of the herpes simplex thymidine kinase promoter linked to the coding region of the luciferase gene. Proteins used for in vitro analysis were made by coupled in vitro transcription and translation in rabbit reticulocyte lysates (TNT, Promega). All proteins were $\left[{ }^{35} \mathrm{~S}\right] \mathrm{me}$ thionine-labeled and analyzed by electrophoresis on $10 \%$ SDSpolyacrylamide gels. Plasmids containing the T7 promoter upstream of the complete coding sequences of human $\operatorname{RXR} \alpha$, NURR 1 , and NGFI-B, respectively (CMX-RXR $\alpha, \mathrm{CMX}-\mathrm{RAR} \alpha$, CMX-NURR1, and CMX-NGFI-B|, were used as templates in these reactions.

\section{Cotransfection assays}

Human chorion carcinoma JEG-3 cells were maintained in Dulbecco's modified Eagle medium (DMEM) supplemented with $10 \%$ fetal calf serum (FCS). Transfections were performed in duplicate in 24-well plates by the calcium phosphate method (Figs. 1, 7B,C,8B,9, and 10) or by lipofection technique using $N$-[1-(2,3-dioleoyloxy/propyl]- $N, N, N$-trimethyl-ammonium methylsulfate (DOTAP, Boehringer Mannheim) as directed by the supplier. Briefly, 1 day prior to transfection, cells were seeded at a density of $2.4 \times 10^{4}$ cells/well using DMEM with $10 \%$ charcoal-stripped FCS. Each well was treated with $50 \mathrm{ng}$ of the indicated expression vectors, $100 \mathrm{ng}$ of reporter plasmid, and 200 ng of reference CMX- $\beta$ gal plasmid containing the $\beta$-galactosidase gene and pGEM-5 (Promega) as carrier DNA up to $500 \mathrm{ng}$ of total DNA. Cells were exposed to calcium phosphate precipitate for $12-15 \mathrm{hr}$ or to DOTAP-DNA for 3-7 hr and washed with PBS, and then fresh medium was added containing $10 \%$ charcoal-stripped FCS and all-trans RA, 9-cis RA, TTNPB (E)4-[2-(5,5,8,8-tetramethyl-5,6,7,8 tetrahydro-2-naphtalenyl)-1propenyl]benzoic acid), SR11237 (Lehmann et al. 1992), or ethanol as indicated. The cells were harvested after $36 \mathrm{hr}$ incubation and lysed, and extracts were assayed for luciferase and $\beta$-galactosidase activity. All luciferase activities were normalized to $\beta$-galactosidase activity. The presented data represent one out of at least three independent transfection experiments. Variation between data points was $<20 \%$.

\section{DNA-binding assays}

For gel mobility retardation assays, indicated species of proteins were incubated with binding buffer. The buffer contained 10 $\mathrm{mm}$ Tris (pH 8.0), $40 \mathrm{mM} \mathrm{KCl}, 0.05 \% \mathrm{NP}-40,6 \%$ glycerol, $1 \mathrm{mM}$ DTT, $0.2 \mu \mathrm{g}$ of poly[d(I-C)] (Pharmacia) except for the experiments displayed in Figures $2 \mathrm{E}, 4 \mathrm{~B}$, and $6 \mathrm{C}$ in which $\mathrm{KCl}$ was added at $20 \mathrm{~mm}$. Approximately $0.2-0.5 \mathrm{ng}$ of ${ }^{32} \mathrm{P}$-labeled probe, which was labeled to a specific activity of about $3 \times 10^{8}$ to $5 \times 10^{8}$ $\mathrm{cpm} / \mu \mathrm{g}$ by fill-in reaction with the Klenow fragment, was added to the reaction and incubated on ice for $20 \mathrm{~min}$. The reactions were then loaded onto $4 \%$ nondenaturing polyacrylamide gels in either $0.5 \times$ or $0.25 \times$ (Figs. $2 \mathrm{E}, 4 \mathrm{~B}$, and $6 \mathrm{C}$ ) TBE running buffer. After electrophoresis, gels were dried for autoradiography. In Figure 2E, $0.25 \mu \mathrm{l}$ of preimmune, anti-hRXR $\alpha$ (Kliewer et al. 1992c), or anti-NGFI-B antiserum (see below) was included in the binding reactions. In the competition experiment shown in Figure 4, relative amounts of proteins were determined from dried and autoradiographed SDS gels run with $\left[{ }^{35} \mathrm{~S}\right]$ methionine-labeled in vitro-translated proteins. The following HREs and their complements were ${ }^{32} \mathrm{p}$-labeled and used as probes as indicated: IR-mix, agcttcaAGGTCAcagctgTGACCTgagagct and the identical oligonucleotides containing spacers cactg, catg, cag, cg, g, ER-mix, agcttcaTGACCT-cagctgAGGTCAgagagct and the identical oligonucleotdes containing spacers cactg, catg, cag, cg, g; BRE-mix, agcttaaggGGTTCAcccgaa-AGTTCActcgcat and the identical oligonucleotides containing spacers ccgaa, cgaa, gaa, aa, a; TREp, agcttcaAGGTCAGACCTgagagct; $\gamma \mathrm{F}$-Cry, agcttgTGACCCTTTAACCAGGTCAg; MHC TRE, agctggAGGTGACAGGAGGACAgcaagct; BRE, agcttaaggGGTTCACCGAAAGTTCActcgcat; NX 3', agcttttAGGTCACCGAAAGGTCActc; NX 5', agcttttAAAGGTCACCGTTAGGTCActc; NBRE, agcttgagttttaAAAGGTCAtgctcaattt.

\section{NGFI-B antiserum}

A fragment corresponding to amino acids $1-150$ of NGFI-B was amplified by the polymerase chain reaction (PCR) and cloned into the bacterial expression vector pGEX-2T (Pharmacia). Bacterial protein was expressed and purified as described (Perlmann et al. 1993). The NGFI-B protein fragment was used to raise a rabbit polyclonal antiserum. The specificity of anti-NGFI-B antibodies was confirmed by supershift experiments in gel mobility-shift assays using NGFI-B and several other receptors synthesized by in vitro translation in rabbit reticulocyte lysates.

\section{Acknowledgments}

We thank Drs. Jeffrey Milbrandt and Orla Conneely for providing cDNAs encoding NGFI-B and NURRl, respectively. Drs. Pierre Chambon and Kazuhiko Umesono and members of Ron Evans' laboratory are acknowledged for plasmids. Jackie Dyck is acknowledged for the gift of hRXR $\alpha$ antibodies. We thank Ulf Eriksson, Arthur Levin, and Richard Heyman for gifts of TTNPB, SR11237, and 9-cis RA, respectively. We also thank Björn Vennström, Reg Williams, Urban Lendahl and Ludmila Solomin for helpful comments on this manuscript. This work was supported by a grant from the Swedish Medical Research Council (project no. B95-13X-10828-02B).

The publication costs of this article were defrayed in part by payment of page charges. This article must therefore be hereby marked "advertisement" in accordance with 18 USC section 1734 solely to indicate this fact.

\section{References}

Allenby, G., M.T. Bocquel, M. Saunders, S. Kazmer, J. Speck, M. Rosenberger, A. Lovey, P. Kastner, J.F. Grippo, P. Chambon, and A.A. Levin. 1993. Retinoic acid receptors and retinoid X receptors: Interactions with endogenous retinoic acids. Proc. Natl. Acad. Sci. 90: 30-34.

Andersson, M.L., K. Nordström, S. Demczuk, M. Harbers, and B. Vennström. 1992. Thyroid hormone alters the DNA binding properties of chicken thyroid hormone receptors alpha 
and beta. Nucleic Acids Res. 20: 4803-4810.

Au-Fliegner, M., E. Helmer, J. Casanova, B.M. Raaka, and H.H. Samuels. 1993. The conserved ninth C-terminal heptad in thyroid hormone and retinoic acid receptors mediates diverse responses by affecting heterodimer but not homodimer formation. Mol. Cell. Biol. 13: 5725-5737.

Baes, M., T. Gulick, H.-S. Choi, M.G. Martinoli, D. Simha, and D.D. Moore. 1994. A new orphan member of the nuclear hormone receptor superfamily that interacts with a subset of retinoic acid response elements. Mol. Cell. Biol. 14: 1544 1552.

Bugge, T.H., J. Pohl, O. Lonnoy, and H.G. Stunnenberg. 1992. RXR alpha, a promiscous partner of retinoic acid and thyroid hormone receptors. EMBO J. 11: 1409-1418.

Cho, K.W. and E.M. De Robertis. 1990. Differential activation of Xenopus homeo box genes by mesoderm-inducing growth factors and retinoic acid. Genes \& Dev. 4: 1910-1916.David, I.J., T.G. Hazel, and L.F. Lau. 1991. Transcriptional activation by Nur77, a growth factor-induced member of the steriod hormone receptor superfamily. Mol. Endocrinol 5:854 859.

Davis, I.J., T.G. Hazel, and L.F. Lau. 1991. Transcriptional activation by Nur77, a growth factor-induced member of the steroid hormone receptor superfamily. Mol. Endocrinol. 5: 854-859.

de Thé, H., M.M. Vivanco-Ruiz, P. Tiollais, H. Stunnenberg, and A. Dejean. 1990. Identification of a retinoic acid responsive element in the retinoic acid receptor beta gene. Nature 343: $177-180$.

Diamond, M.I., J.N. Miner, S.K. Yoshinaga, and K.R. Yamamoto. 1990. Transcription factor interactions: Selectors of positive or negative regulation from a single DNA element. Science 249: 1266-1272.

Durand, B., M. Saunders, P. Leroy, M. Leid, and P. Chambon. 1992. All-trans and 9-cis retinoic acid induction of CRABPII transcription is mediated by RAR-RXR heterodimers bound to DR1 and DR2 repeated motifs. Cell 71: 73-85.

Evans, R.M. 1988. The steroid and thyroid hormone receptor superfamily. Science 240: 889-895.

Fields, S. and O. Song. 1989. A novel genetic system to detect protein-protein interactions. Nature 340: 245-246.

Forman, B.M., C.-R. Yang, M. Au-Fliegner, J. Casanova, J. Ghysdael, and H.H. Samuels. 1989. A domain containing leucinezipper-like motifs mediate novel in vivo interactions between the thyroid hormone and retinoic acid receptors. Mol. Endocrinol. 3: 1610-1626.

Forman, B.M., J. Casanova, B.M. Raaka, J. Ghysdael, and H.M. Samuels. 1992. Half-site spacing and orientation determines whether thyroid hormone and retinoic acid receptors and related factors bind to DNA response elements as monomers, homodimers, or heterodimers. Mol. Endocrinol. 6: $429-442$.

Giguere, V., E.S. Ong, P. Segui, and R.M. Evans. 1987. Identification of a receptor for the morphogen retinoic acid. Nature 330: 624-629.

Giguere, V., M. Tini, G. Flock, E. Ong, R.M. Evans, and G. Otulakowski. 1994. Isoform-specific amino-terminal domains dictate DNA-binding properties of RORalpha, a novel family of orphan hormone nuclear receptors. Genes \& Dev. 8: $538-553$.

Glass, C.K., S.M. Lipkin, O.V. Devary, and M.G. Rosenfeld. 1989. Positive and negative regulation of gene transcription by a retinoic acid-thyroid hormone receptor heterodimer. Cell 59: 697-708.

Green, S. and P. Chambon. 1988. Nuclear receptors enhance our understanding of transcription regulation. Trends Genet.
4: 889-895.

Harding, H.P. and M.A. Lazar. 1993. The orphan receptor RevErbAalpha activates transcription via a novel response element. Mol. Cell. Biol. 13: 3113-3121.

Hazel, T.G., D. Nathans, and L.F. Lau. 1988. A gene inducible by serum growth factors encodes a member of the steroid and thyroid hormone receptor family. Proc. Natl. Acad. Sci. 85: 8444-8448.

Hendry, I.A. and D.A. Belford. 1991. Retinoic acid potentiates the neurotrophic but not the mitogenic action of the class 1 heparin-binding growth factor (HBGF-1). Brain Res. 542: 2934.

Hermann, T., B. Hoffmann, X.-K. Zhang, P. Tran, and M. Pfahl. 1992. Heterodimeric receptor complexes determine $3,5,3^{\prime}$ triiodothyronine and retinoid signaling specificities. Mol. Endocrinol. 6: 1153-1162.

Herschman, H.R. 1991. Primary response genes induced by growth factors and tumor promoters. Annu. Rev. Biochem. 60: 281-319.

Heyman, R.A., D.J. Mangelsdorf, J.A. Dyck, R.B. Stein, G. Eichele, R.M. Evans, and C. Thaller. 1992.9-cis retinoic acid is a high affinity ligand for the retinoid $\mathrm{X}$ receptor. Cell 68: $397-406$

Iwata, M., M. Mukai, Y. Nakai, and R. Iseki. 1992. Retinoic acid inhibits activation-induced apoptosis in $\mathrm{T}$ cell hybridomas and thymocytes. J. Immunol. 149: 3302-3308.

Katz, R.W. and R.J. Koenig. 1993. Nonbiased identification of DNA sequences that bind thyroid hormone receptor alphal with high affinity. J. Biol. Chem. 268: 19392-19397.

Kent, T.A., J.L. Messina, R.S. Weinstock, and J.P. Stein. 1994. Synergistic induction of gene 33 expression by retinoic acid and insulin. Endocrinology 134: 2237-2244.

Kliewer, S.A., K. Umesono, D.J. Mangelsdorf, and R.M. Evans. 1992a. Retinoid X receptor interacts with nuclear receptors in retinoid acid, thyroid hormone and vitamin D3 signalling. Nature 355: 446-449.

Kliewer, S.A., K. Umesono, D.J. Noonan, R.A. Heyman, and R.M. Evans. 1992b. Convergence of 9-cis retinoic acid and peroxisome proliferator signalling pathways through heterodimer formation of their receptors. Nature 358: 771-774.

Kliewer, S.A., K. Umesono, R.A Heyman, D.J. Mangelsdorf, J.A. Dyck, and R.M. Evans. 1992c. Retinoid X receptor-COUPTF interactions modulate retinoic acid signaling. Proc. Natl. Acad. Sci. 89: 1448-1452.

Kurie, J.M., P. Brown, E. Salk, D. Scheinberg, M. Birrer, P. Deutsch, and E. Dmitrovsky. 1993. Cooperation between retinoic acid and phorbol exters enhances human teratocarcinoma differentiation. Differentiation 54: 115-122.

Kurokawa, R., V.C. Yu, A. Näär, S. Kyakumoto, Z. Han, S. Silverman, M.G. Rosenfeld, and C.K. Glass. 1993. Differential orientations of the DNA-binding domain and carboxy-terminal dimerization interface regulate binding site selection by nuclear receptor heterodimers. Genes \& Dev. 7: 1423-1435.

Kurokawa, R., J. DiRenzo, M. Boehm, J. Sugerman, B. Gloss, M.G. Rosenfeld, R.A. Heyman, and C.K. Glass. 1994. Regulation of retinoid signaling by receptor polarity and allosteric control of ligand binding. Nature 371: 528-531.

Law, S.W., O.M. Conneely, F.J. DeMayo, and B.W. O'Malley. 1992. Identification of a new brain-speicific transcription factor, NURR1. Mol. Endocrinol. 6: 2129-2135.

Lehmann, J.M., L. Jong, A. Fanjul, J.F. Cameron, X.P. Lu, P. Haefner, M.I. Dawson, and M. Pfahl. 1992. Retinoids selective for retinoid $\mathrm{X}$ receptor response pathways. Science 258: 1944-1946.

Leid, M.P., R. Kastner, R. Lyons, H. Nakshatri, M. Saunders, T. Zacharewski, J.Y. Chen, A. Staub, J.M. Garnier, S. Mader, 
and P. Chambon. 1992. Purification, cloning and RXR identity of the HeLa cell factor with which RAR or TR heterodimers bind to target sequences efficiently. Cell 68: $377-$ 395.

Levin, A.A., L.J. Sturzenbecker, S. Kazmer, T. Bosakowski, C. Huselton, G. Allenby, J. Speck, C. Kratzeisen, M. Rosenberger, A. Lovey, and J.F. Grippo. 1992. 9-cis retinoic acid steroisomer binds and activates the nuclear receptor RXR alpha. Nature 355: 359-361.

Li, J. and A.C. Sartorelli. 1992. Synergistic induction of the differentiation of WEHI-3B D + myelomonocytic leukemia cells by retinoic acid and granulocyte colony-stimulating factor. Leuk. Res. 16: 571-576.

Liu, Z.-G., S.W. Smith, K.A. McLaughlin, L.M. Schwartz, and B.A. Osborne. 1994. Apoptotic signals delivered through the T-cell receptor of a T-cell hybrid require the immediateearly gene nur77. Nature 367: 281-284.

Mader, S., P. Leroy, J.-Y. Chen, and P. Chambon. 1993a. Multiple parameters control the selectivity of nuclear receptors for their response elements. J. Biol. Chem. 268: 591-600.

Mader, S., J.-Y. Chen, Z. Chen, J. White, P. Chambon, and H. Gronemeyer. 1993b. The patterns of binding of RAR, RXR and TR homo- and heterodimers to direct repeats are dictated by the binding specificities of the DNA binding domains. EMBO J. 12: 5029-5041.

Mangelsdorf, D.J., E.S. Ong, J.A. Dyck, and R.M. Evans. 1990. Nuclear receptor that identifies a novel retinoic acid response pathway. Nature 345: 224-229.

Mangelsdorf, D.J., K. Umesono, S.A. Kliewer, U. Borgmeyer, E.S. Ong, and R.M. Evans. 1991. A direct repeat in the cellular retinol-binding protein type II confers differential regulation by RXR and RAR. Cell 66: 555-561.

Mangelsdorf, D.J., U. Borgmeyer, R.A. Heyman, J.Y. Zhou, E.S. Ong, A.E. Oro, A. Kakizuka, and R.M. Evans. 1992. Characterization of three RXR genes that mediate the action of 9-cis retinoic acid. Genes \& Dev. 6: 329-344.

Marks, M.S., P.L. Hallenbeck, T. Nagata, J.H. Segars, E. Appella, V.M. Nikodem, and K. Ozato. 1992. H-2RIIBP (RXR beta) heterodimerization provides a mechanism for combinatorial diversity in the regulation of retinoic acid and thyroid hormone responsive genes. EMBO I. 11: 1419-1435.

Milbrandt, J. 1988. Nerve growth factor induces a gene homologous to the slucocorticoid receptor gene. Neuron 1: 183188.

Miner, J.N. and K.R. Yamamoto. 1991. Regulatory crosstalk at composite response elements. Trends Biochem. Sci. 16: 423-426.

Miyamoto, T., S. Suzuki, and L.J. deGroot. 1993. High affinity and specificity of dimeric binding of thyroid hormone receptors to DNA and their ligand dependent dissociation. Mol. Endocrinol. 7: 224-231.

Näär, A.M., J.-M. Boutin, S.M. Lipkin, V.C. Yu, J.M. Holloway, C.K. Glass, and M.G. Rosenfeld. 1991. The orientation and spacing of core DNA-binding motifs dictate selective transcriptional responses to three nuclear receptors. Cell 65: 1267-1279.

Nagpal, S., S. Friant, H. Nakshatri, and P. Chambon. 1993. RARs and RXRs: Evidence for two autonomous transactivation functions (AF-1 and AF-2) and heterodimerization in vivo. $E M B O$ T. 12: 2349-2360.

Pearce, D. and K.R. Yamamoto. 1993. Mineralocorticoid and glucocorticoid receptor activities distinguished by nonreceptor factors at a composite response element. Science 259: 1161-1165.

Perlmann, T., P.N. Rangarajan, K. Umesono, and R.M. Evans. 1993. Determinants for selective RAR and TR recognition of direct repeat HREs. Genes \& Dev. 7: 1411-1422.

Pfahl, M. 1993. Nuclear receptor/AP-1 interaction. Endocr. Rev. 14: 651-658.

Sadowski, I. and M. Ptashne. 1989. A vector for expressing GAL4(1-147) fusions in mammalian cells. Nucleic Acids Res. 17: 7539.

Scearce, L.M., T.M. Laz, T.G. Hazel, L.F. Lau, and R. Taub. 1993. RNR-1, a nuclear receptor in the NGFI-B/Nur77 family that is rapidly induced in regenerating liver. $J$. Biol. Chem. 268: 8855-8861.

Schräder, M., M. Becker-André, and C. Carlberg. 1994a. Thyroid hormone receptor functions as monomeric ligand-induced transcription factor on octameric half-sites. Consequences also for dimerization. J. Biol. Chem. 269: 6444-6449.

Schräder, M., K.M. Müller, S. Nayeri, J.-P. Kahlen, and C. Carlberg. 1994b. Vitamin $\mathrm{D}_{3}$-thyroid hormone receptor heterodimer polarity directs ligand sensitivity of transactivation. Nature 370: 382-386.

Schüle, R., P. Rangarajan, N. Yang, S. Kliewer, L.J. Ransone, J. Bolado, I.M. Verma, and R.M. Evans. 1991. Retinoic acid is a negative regulator of AP-1-responsive genes. Proc. Natl. Acad. Sci. 88 6092-6096.

Sporn, M.B., A.B. Roberts, and D.S. Goodman. 1984. The retinoids, vols. 1 and 2. Academic Press, New York.

Sucov, H.M., K.K. Murakami, and R.M. Evans. 1990. Characterization of an autoregulated response element in the mouse retinoic acid receptor type beta gene. Proc. Natl. Acad. Sci. 87: 5392-5396.

Sugawara, A., P.M. Yen, D.S. Darling, and W.W. Chin. 1993. Characterization and tissue expression of multiple triiodothyronine receptor-auxiliary proteins and their relationship to the retinoid X-receptors. Endocrinology 133: 965-971.

Tini, M., G. Otulakowski, M.L. Breitman, L.-C. Tsui, and V. Giguere. 1993. An everted repeat mediates retinoic acid induction of the gamma F-crystallin gene: Evidence of a direct role for retinoids in lens development. Genes \& Dev. 7: 295307.

Towers, T.L., B.F. Luisi, A. Asianov, and L.P. Freedman. 1993. DNA target selectivity by the vitamin D3 receptor: Mechanism of dimer binding to an asymmetric repeat element. Proc. Nat1. Acad. Sci. 90: 6310-6314.

Ueda, H., G.-C. Sun, T. Murata, and S. Hirose. 1992. A novel DNA-binding motif abuts the zinc finger domain of insect nuclear hormone receptor FTZ-F1 and mouse embryonal long terminal repeat-binding protein. Mol. Cell. Biol. 12: $5667-5672$.

Umesono, K., V. Giguere, C.K. Glass, M.G. Rosenfeld, and R.M. Evans. 1988. Retinoic acid and thyroid hormone induce gene expression through a common responsive element. Nature 336: $262-265$.

Umesono, K., K.K. Murakami, C.C. Thompson, and R.M. Evans. 1991. Direct repeats as selective response elements for the thyroid hormone, retinoic acid, and vitamin D3 receptors. Cell 65: 1255-1266.

Vivanco-Ruiz, M.M., T.H. Bugge, P. Hirschmann, and H.G. Stunnenberg. 1991. Functional characterization of a natural retinoic acid responsive element. EMBO I. 10: 3829-3838.

Wilson, T.E., T.J. Fahrner, M. Johnston, and J. Milbrandt. 1991. Identification of the DNA binding site for NGFI-B by genetic selection in yeast. Science 252: 1297-1300.

Wilson, T.E., A.R. Mouw, C.A. Weaver, J. Milbrandt, and K.L. Parker. 1993a. The orphan nuclear receptor NGFI-B regulates expression of the gene encoding steroid 21-hydroxylase. Mol. Cell. Biol. 13: 861-868.

Wilson, T.E., T.J. Fahrner, and J. Milbrandt. 1993b. The orphan receptors NGFI-B and steroidogenic factor 1 establish mono- 
mer binding as a third paradigm of nuclear receptor-DNA interaction. Mol. Cell. Biol. 13: 5794-5804.

Woronicz, J.D., B. Calnan, V. Ngo, and A. Winoto. 1994. Requirement for the orphan steroid receptor Nur77 in apoptosis of T-cell hybridomas. Nature 367: 277-280.

Yang, Y., M.S. Vacchio, and J.D. Ashwell. 1993. 9-cis-retinoic acid inhibits activation-driven $\mathrm{T}$-cell apoptosis: Implications for retinoid $\mathrm{C}$ receptor involvement in thymocyte development. Proc. Nat1. Acad. Sci. 90: 6170-6174.

Yang Yen, H.-F., X.-K. Zhang, G. Graupner, M. Tzukerman, B. Sakamoto, M. Karin, and M. Pfahl. 1991. Antagonism between retinoic acid receptors and AP-1: Implication for tumor promotion and inflammation. New Biol. 3: 1216-1219.

Yu, V.C., C. Delsert, B. Andersen, J.M. Holloway, O.V. Devary, A.M. Näär, S.Y, Kim, J.M. Boutin, C.K. Glass, and M.G. Rosenfeld. 1991. RXR beta: A coregulator that enhances binding of retinoic acid, thyroid hormone and vitamin $\mathrm{D}$ receptors to their cognate response elements. Cell 65: 12511266.

Zechel, C., X.-Q. Shen, J.-Y. Chen, Z.-P. Chen, P. Chambon, and H. Gronemeyer. 1994a. The dimerization interfaces formed between the DNA binding domains of RXR, RAR and TR determine the binding specificity and polarity of the fulllength receptors to direct repeats. EMBO I. 13: 1425-1433.

Zechel, C., X.-Q. Shen, P. Chambon, and H. Gronemeyer. 1994b. Dimerization interfaces formed between the DNA binding domains determine the cooperative binding of RXR/ RAR and RXR/TR heterodimers to DR5 and DR4 elements. EMBO I. 13: 1414-1424.

Zhang, X.K., B. Hoffmann, P.B. Tran, G. Graupner, and M. Pfahl. 1992a. Retinoid X receptor is an auxiliary protein for thyroid hormone and retinoic acid receptors. Nature 355: 441-446.

Zhang, X.K., J. Lehmann, B. Hoffmann, M.I. Dawson, J. Cameron, G. Graupner, T. Hermann, P. Tran, and M. Pfahl. 1992b. Homodimer formation of retinoid X receptor induced by 9-cis retinoic acid. Nature 358: 587-591.

Zhang, X.K., G. Salbert, M.O. Lee, and M. Pfahl. 1994. Mutations that alter ligand-induced switches and dimerization activities in the retinoid $\mathrm{X}$ receptor. Mol. Cell. Biol. 14: $4311-4323$. 


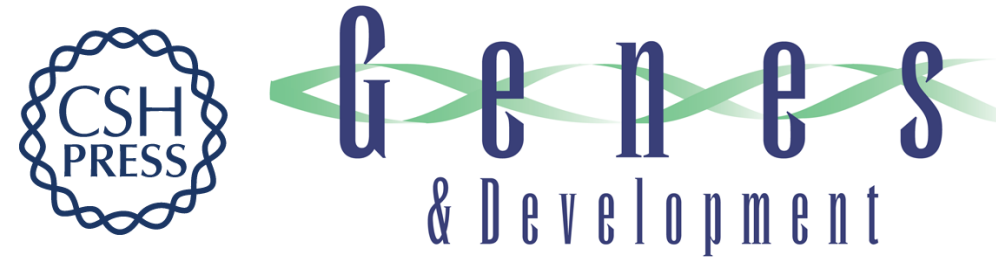

\section{A novel pathway for vitamin A signaling mediated by RXR heterodimerization with NGFI-B and NURR1.}

T Perlmann and $L$ Jansson

Genes Dev. 1995, 9:

Access the most recent version at doi:10.1101/gad.9.7.769

References This article cites 79 articles, 29 of which can be accessed free at:

http://genesdev.cshlp.org/content/9/7/769.full.html\#ref-list-1

License

Email Alerting

Service

Receive free email alerts when new articles cite this article - sign up in the box at the top right corner of the article or click here.

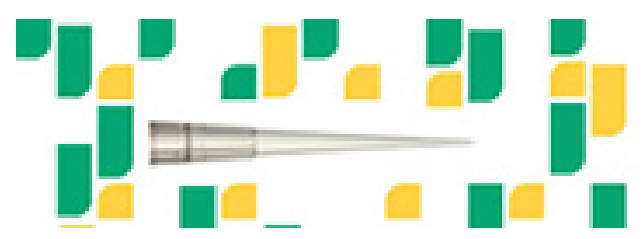

Focused on your science.

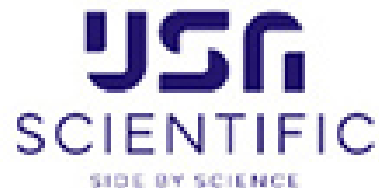

Copyright (C) Cold Spring Harbor Laboratory Press 